\title{
Woman and Authority in Ian McEwan's "Conversation with a Cupboard Man" and Its Film Adaptation
}

\section{ABSTRACT}

The paper analyzes Ian McEwan's short story “Conversation with a Cupboard Man” (published in 1975) and its film adaptation made in Poland by director Mariusz Grzegorzek in 1993. In many works McEwan shows women in more positive light than men. This short story, however, deals with a mother's total domination of her son's life. The text is in the form of first-person narration of the son but it is the figure of the mother that is of utmost importance.

The protagonist describes his life from his childhood. His mother wanted him to remain a baby as long as possible, depriving him of free will and leaving him totally dependent on her. Her attitude changed when she found a partner. The protagonist, now seventeen, had rapidly to grow up from a baby into an adult. Childhood and total passivity remain for him ideals to be pursued, and a cramped cupboard becomes his favourite environment. The influence of his upbringing remains with him for ever. After analyzing the short story the paper explores parallels to other works by McEwan and other writers. The importance of the use of the indeterminate article in the title is discussed. Attention is given to the issue of defamiliarization. And the ambivalent attitude of the protagonist towards his mother is examined.

The second part of the paper deals with the film adaptation. Grzegorzek has imaginatively developed the short story into a full-blown feature film. It preserves most of the important elements of the short story, at the same time providing new material largely in keeping with the original's tone. The director not only extrapolates, inventing new scenes to fill in the short story's unspoken gaps but also skilfully changes the narrator's comments into scenes, and this is not purely a change from telling into showing. The paper discusses the imagery of the movie, especially Oedipal motifs, references to Christ, and the impression 
of blood-red lips. It stresses the stronger role of the teacher from the home (Smith in the text) and his influence on the only independent action of the protagonist-the revenge on Pus-face. It is also important that the film omits any verbal expression of the protagonist's hatred towards his mother.

\section{Abstract}

McEwan's "Conversation with a Cupboard Man" is a short story published in his very first book, the collection First Love, Last Rites, in 1975. ${ }^{1}$ The story is only a dozen pages long but it was the basis for a full-blown feature film Rozmowa z cztowiekiem z szafy (Conversation with a Cupboard Man), made in Poland by director Mariusz Grzegorzek in 1993. The movie was received favourably, winning several prizes at international film festivals, including the award for best first work in Venice in 1993. It creatively develops McEwan's motifs and thus deserves to be discussed together with the short story that inspired it.

In McEwan women are often shown in a more positive light than their male partners. At the same time they can be more passive, too. We see this in his earliest short stories. In "Homemade," Connie, the ten-year-old sister of the protagonist, is a victim of her brother's incestuous desire but were it not for her knowledge of what posture to take and how to use their bodies, the whole thing would have ended in nothing; used by him, she remains somehow superior in her know-how. In "Pornography" (from the other short story collection, In Between the Sheets, 1978), two women are quickly seduced by O'Byrne and try hard to please him until they find out about his unfaithfulness; only then do they become active and take cruel revenge on him. A similar pattern can be traced in his novels. In The Child in Time, Julie's passive way of coping with the loss of their child is at least as good as the active one preferred by Stephen; in the other couple in the story, Thelma is not only Charles's wife, but in some respects she has also to mother him. In The Innocent Maria introduces Leonard into the world of sexuality and thus leads him from innocence to maturity. As Jack Slay, Jr. states, “[m] uch of McEwan's literature of shock [i.e. his early output] portrays the brutalization and mistreatment of women by a patriarchal so-

1 The story appeared originally in the 1972 Spring-Summer issue of Transatlantic Review (cf. Slay 20). 
ciety; as he begins to mature as a writer, his approach to the relationships between men and women becomes increasingly more feminist" (7). A list of McEwan's works that follow this pattern could go on. "Conversation with a Cupboard Man" can be treated not as misogyny but an attempt to explore new territory.

The story is presented in first-person narration, and it is the nameless narrator who is the main character. However, it is the female character, his mother, who plays the primary role and who stands behind almost all his actions.

The narrator's father died before he was born. His mother's aim in life was to have children. As she would not consider another marriage he remained her only child and "had to be all the children she had ever wanted" (75). For this reason, she tried to make him remain her small baby as long as possible. She did not pay attention to his physical growth. He was not sent to school, he slept in a cot, and when he grew too big for it she "bought a crib bed from a hospital auction" (75). She wanted to keep him "living [his] first two years over and over again" (76), tying a bib round his neck and feeding him. He did not even think about protesting against this as he did not know any other kind of life and, as he says, "how could I run away when I would be shitting myself with terror before I got fifty yards down the street?" (76).

And then came suddenly change. His mother, still attractive at thirtyeight, met a man who fascinated her. "Overnight she just swapped obsessions and all the sex she'd missed out on caught up with her" (77). She wanted to ask the man home but then she would have to show him her seventeen-year-old son who behaved like a small baby. Thus the boy had to grow up very quickly: “That's why in two months I had a lifetime's growing up to do" (77). One day his mother marries her lover and tells her son that he should call him Father. The boy has a fit; he has had them before but this one is the worst of all. When he regains consciousness:

[I] saw the look on my mother's face, complete disgust it was. You've no idea how much a person can change in such a short time. When I saw that look I realized she was as much a stranger to me as my father. (78)

The narrator moves into the world. First he is sent to an institution, most probably to a home for the mentally handicapped. He says: "there were all kinds of weird people there and that made me feel more sure of myself" (78). He learns to read and write, gets some job qualifications, and, most importantly, is taught by one of the teachers, Mr Smith, how to express himself through dancing and painting. The pictures he paints are worthy of psychiatric analysis. When he is asked to paint his mother: 
"I made large red mouths all over the paper-that was her lipstick-and in the mouths I painted it black. That was because I hated her. Though I didn't really" (79). This double attitude, of hatred and attraction, runs through other parts of his story.

When he is twenty-one he has to start living on his own. He goes to London and finds a job-washing up dishes in a hotel restaurant. There he becomes the object of persecution of the physically repellent, mentally disgusting chief cook. Because of numerous awful scabs on the cook's face the narrator calls him "Pus-face". The Cupboard $\mathrm{Man}^{2}$ is instructed to clean the main oven, and has to get inside it, but is then locked in. This is the cook's idea of a joke. The young man spends five hours in the oven. On the following day he is told to get in again but this time the cook turns on the heat. When the boy finally gets out he has serious burns on his feet and back. The next day he comes to the restaurant kitchen intent on revenge. He throws four pints of boiling oil into the cook's lap, practically castrating him, apt punishment, perhaps, for a man who not only plays cruel jokes but reads "dirty magazines" (82) and chases after women working in the kitchen.

After this the Cupboard Man is too ill to stay in the kitchen, and cannot find other work. He returns home to find that his mother and her new husband have left without leaving a forward address. Then he starts shoplifting. Finally, he is caught red-handed and sent to prison. Strangely enough, the prison turns out not to be so bad:

My cell wasn't very different from my room in Muswell Hill [the institution in which he stayed till becoming twenty-one]. In fact from the window there was a much better view from my prison room because I was higher up.... You could cut pictures out of magazines and stick them on the wall, and I wasn't allowed to do that in my room in Muswell Hill. (85)

In his opinion, these "three months were the best since I left home" (86). He enjoys the quiet routine of the days: "Each day was like the one before it. I didn't have to worry about meals and rent. Time stood still for me, like floating on a lake. I began to worry about coming out" (86). $\mathrm{He}$ even asks the assistant governor whether he could stay on but "he said it cost sixteen pounds a week to keep a man inside, and that there were plenty of others waiting to come in. They didn't have room for us all” (86).

2 Naming a character is useful for critics; that very spelling has been already used in criticism and that is why it is repeated here. However, it should be observed that as in the edition of First Love, Last Rites used in this paper the titles of all short stories are written without capitalization, McEwan did not mean to capitalize that "name." In that edition the story is called "Conversation with a cupboard man." 
When released, he finds menial work in a factory which he does not mind "because it was so noisy that you didn't have to speak to anyone" (86). Gradually he stops going to work and starts spending more and more time in a wardrobe containing no clothes but only cushions and blankets. At the moment of narration he has not been to his workplace for three months. He says: "I hate going outside. I prefer it in my cupboard" (89).

In the chronology of the story his fascination with a closed space seems to have surfaced for the first time when he reflects on his being locked in the oven:

I thought about that oven a lot. I made up daydreams about being made to stay inside an oven. That sounds incredible, especially after what I did to Pus-face. It was what I felt, though, and I couldn't help that. The more I thought about it, the more I realized that when I went to clean the oven the second time I was secretly wanting to be shut in. I was sort of hoping it without knowing it, do you see what I mean? I wanted to be frustrated. I wanted to be where I couldn't get out. That was at the bottom of my mind. (83)

He compares it with his time in prison as follows:

You might be thinking that what I said about being locked in an oven was the same thing as being locked in a cell. No, it wasn't the painpleasure of feeling frustrated. It was a deeper pleasure of feeling safe. In fact I remember now wishing sometimes I had less freedom. (86)

But the motif of the oven recurs: "Ever since that oven, I want to be contained. I want to be small” (86). That statement can be clearly understood as his wishing to return to his early childhood, or even to the womb, and is expressed in the sentences opening the penultimate paragraph:

I don't want to be free. That's why I envy these babies I see in the street being bundled and carried about by their mothers. I want to be one of them. Why can't it be me? Why do I have to walk around, go to work, cook my meals and do all the hundred things you have to do each day to keep alive? I want to climb in the pram. (87)

The Cupboard Man is the first of a whole series of McEwan characters who try to regress to childhood (cf. Ryan 8 ). Similar attempts at regaining the lost happiness of the early phase of one's life can be found for example in The Cement Garden (Tom, and partly Jack), The Child in Time (Charles Drake), or the television play Jack Flea's Birthday Celebration. David Malcolm comes up with another qualification, seeing him as one 
of the series of "the alienated, the losers, the isolated and marginalized figures" (33), appearing in many McEwan short stories.

A mother's disastrous influence on her son's life is nothing new in literature. One of the best known examples might be Sons and Lovers by D.H. Lawrence, in which the mother dominates the life of her sons, compensating for her disappointment with her husband; however, the novel ends on an optimistic note: Paul Morel decides finally to throw away the despotism of his dead mother. Another instance is Angus Wilson's short story "Mother's Sense of Fun" (from the collection The Wrong Set) which might be read as a pastiche of Sons and Lovers, but going a step further-the death of the protagonist's mother changes nothing in his life; what she has bred in him will remain in his psyche till his death and direct all his actions. Incidentally, Angus Wilson was one of McEwan's tutors during his course of creative writing at the University of East Anglia (a course in which he was the very first student, and in this first year the only one); it was during that course that "Conversation with a Cupboard Man" was written. McEwan described the reaction of his tutors to that story in an interview with William Leith: "Angus [Wilson] liked the nastiness. Malcolm [Bradbury] was pleased with the literary pastiche" (qtd. in Byrnes 64). In another interview McEwan expands on his use of pastiche:

I very much admired The Collector. I still do. I think it's Fowles's best book. In "Conversation with a Cupboard Man" I wanted to do the kind of voice of the man in The Collector: that kind of wheedling, self-pitying lower middle-class voice. (Hamilton qtd. in Childs 11)

McEwan presents the story in the form of the narrator talking to a social worker. The presence of the other person can be gathered only because the narrator addresses him in his speech. From the very beginning McEwan hooks the attention of the reader by presenting the story as a puzzle:

You ask me what I did when I saw this girl. Well, I'll tell you. You see the cupboard there, it takes up most of the room. I ran all the way back there, climbed inside and tossed myself off. Don't think I thought about the girl while I did it. No, I couldn't bear that. I went back in my mind till I was three feet high. That made it come quicker. (75)

Masturbation here is a paradoxically asexual act, and throughout the story sexuality seems of little real importance for the main character. What really attracts his attention is the lost happiness of his early childhood. The cupboard is so alluring because it reproduces the claustrophobic conditions of the womb.

The story is characterized by defamiliarization of the topic. Cowley states that according to McEwan the aim of the artist is to "deanesthetize 
the familiar'-by which he means that the world around us, the world to which we have come to consciousness from babyhood, has a wonder with which we have become too familiar" (Cowley qtd. in Malcolm 41). The creation of a deranged character makes it possible to present problems already treated in literature in an original way.

An interesting feature of the title is the use of the indefinite article, making the main character a representative of an imaginary group of people-Cupboard Men. His experiences might seem to have a wider basis than just the life of an individual. Kiernan Ryan puts it this way: "It is the hidden emotional history of many men, grotesquely caricatured as the confession of a madman" (Ryan 8). Although the word "madman" seems to be too strong in the case of the Cupboard Man, his mind has certainly been seriously disturbed. The use of "a" in the title seems to overrule the words of the narrator: "There can't be many like me" (87).

The attitude of the narrator towards his mother is of a mixed nature. On the one hand, he is very critical of her: "She was twisted up, you know, that's where I got it from" (75), "She was insane" (76). He calls her a "bitch" (76). But at the same time he says of his childhood: "I'll tell you a funny thing. I wasn't unhappy, you know. She was all right really" (76). When he recalls the time she read him stories, or helped him make a toy theatre out of a fruit box he says: "She was a good woman really, my mother. Just twisted, that's all” (76).

Things changed considerably when the mother found a man. "She went mad for this fellow, as if she wasn't mad already" (77). Her attitude towards her child suddenly changed—she wanted him to grow up and perform all those functions she had so far denied him. When this does not happen quickly enough she decides to present him as "mentally subnormal" (77) to her lover. The man does not like the boy: "because he was big and successful he hated me at first sight. ... First time he just nodded when my mother introduced me to him and after he never said a word to me" (77). The attitude is reciprocated: "I hated him because he had taken my mother" (77). The Cupboard Man states that after the fit he suffered following their wedding he saw disgust in his mother's face and realized how much she had changed, becoming a stranger to him. But after he has lost his job at the restaurant he decides to return home:

I began to think back to the old days when I was with my mother. I wished I was back there. The old cotton-wool life when everything was done for me, warm and safe. It sounds pretty stupid, I know, but I started thinking that perhaps my mother had got tired of that man she had married and that if I went back we could carry on the old life. (82) 
This turns out to be impossible, as his mother and her husband have disappeared. Thus what remains for the main character is to try and return to an environment reminding him of the old safety. The wardrobe. To enhance the effect of this "womb" he adds to it a reminder of his childhood days:

The other day I stole a blanket from a pram. I don't know why, I suppose I had to make contact with their world, to feel I was not completely irrelevant to it.... I keep that blanket I stole in the cupboard. I want to fill it with dozens like it. (87)

When talking about his attitude towards his mother it seems appropriate to return to the scene of painting in the home. His words "That was because I hated her. Though I didn't really" (79) might suggest that the red colour used for painting her lips might not have been used only to render her lipstick, as the narrator suggested, but might stand for his love (the black inside expressing his hatred).

The mother's irresponsible attitude of first monopolizing her child, blocking all his contacts with the outside world and keeping him in an artificial state of prolonged infancy, then rejecting him and leaving him on his own, totally unprepared to cope with the world, is additionally strengthened in the short story by means of being presented in the form of a confession of the victim of her egoism.

$$
* * *
$$

Mariusz Grzegorzek's film adaptation is very rarely mentioned in McEwan criticism in English. McEwan himself knows it. In an interview with Jerzy Jarniewicz he mentioned that he had received a copy of the film from the director himself. However, he limited his comment to the statement that it was a very good film, strange and depressing but then the short story itself was depressing - and he then talked about the packet in which the film arrived: a letter with a wax stamp, tied with strings, truly a sculpture (22). Among critics, only C. Byrnes appears to mention the film (64) but even she says little. ${ }^{3}$

A film lives in a different sphere of contexts, and film critics have a different set of references from literary critics. Grzegorzek's film has been compared to works by Ingmar Bergman, especially those touching the results of overprotective motherly love. Some critics have seen a similarity of the main character to Kaspar Hauser from Werner Herzog's

\footnotetext{
3 Byrnes erroneously changes the title of the movie, using the first noun in plural ("Rozmowy") but then she makes the same mistake for the short story itself, calling it "Conversations with a Cupboard Man."
} 
movie-a mysterious character raised in isolation from the world, then suddenly left in the middle of throbbing city life (cf. kjz). ${ }^{4}$ It can also be treated as expressing the views of the director himself. In an article in the Polish monthly Kino, Mariusz Grzegorzek wrote: "I feel bad. The art as I feel and understand it, is treated today as a misunderstanding, it has lost its impact. I would like to save-for myself and others-this intensive emotion, this way of looking at the world, which gave me the strength to live" (Grzegorzek 13, translation mine).

Grzegorzek's movie is an interesting development of McEwan's short story and it is a pity that there has been little comparison of both works. It preserves most of the important elements of the short story, at the same time providing new material largely in keeping with the original. It is not only that the director has to extrapolate, inventing new scenes to fill in untold gaps in the story (for example, the scenes showing the problems with education authorities who want to make the boy attend a school). Grzegorzek skilfully changes the narrator's comments into scenes, and this is not purely a change from telling to showing. One of the most important elements is the rendering of the attitude towards the mother. The short story is marked by a mixed attitude of the narrator towards his mother - one of hatred and love. In the film, Karol does not pronounce a single negative word against his mother. Neither in direct speech nor in the voice-over fragments expressing his thoughts do we hear that he hates her. What remains from the book are his comments that she is strange, very strange, and somehow twisted. He also says that he misses his mother and longs for her. However, the viewers can make their own judgements on the basis of the mother's actions.

The film makes the mother even more important than she is in the short story. She is continually present on screen in the first half, until the boy is sent to the home, and in the second half she still appears in his dreams.

The narrator of the short story describes himself as "thin and bloodless" (77). The choice of Rafał Olbrychski for this role is a bull's-eye-he fits this description perfectly. This impression is enhanced by his posture, expressing his total lack of self-confidence. The contrast between the two characters, mother and son, is striking.

The film opens with an extreme close-up of a picture of Christ, starting with his exposed heart. Then the camera tracks back to show the whole painting. This has a double importance. On the one hand, it introduces the character of the rooms in the film-both the home flat of Karol (this is the name of the Cupboard Man in the film) and the room he rents later have

4 Grzegorzek himself names Bergman and Herzog among those artists who influenced him during his studies (12). 
many religious pictures on the walls. On the other hand, several scenes showing the adult Karol are shot in a way that likens him to Christ in a pietà. One more scene should be mentioned in this context: after the new "father" has been introduced to the boy and he falls into a fit we are shown a close-up of a picture of the Holy Virgin; then canted framing is used, ${ }^{5}$ the angle becoming more and more oblique, so that Mary appears to bow her head in compassion.

The action of the film starts dramatically. After a short scene with the voice-over in which Karol says that he feels fine, that he does not need any change, that he prefers to stay here, in his cupboard, we move to a morgue. On seeing the dead body of her husband, Karol's mother has contractions and is clearly going to give birth to Karol. Thus from the very beginning Karol is shown as a replacement for her dead partner.

Grzegorzek has added two scenes intended to express the mother's attitude to Karol. The first shows her feeding the baby Karol with gruel; in the middle of the plate is a strawberry that, according to her words, is meant for the kid as a reward at the end of the meal. She treats the child with tenderness, giving him spoonful after a spoonful until he tries to grasp the fruit. Whereupon she shouts at him and slaps him violently. The other scene is connected with a visit by a postwoman, who gives Karol, now eight years old, a sweet. When she is gone, the mother takes the sweet away from him and says that it must surely be poisoned. She puts it into her mouth and in a second starts shouting with pain and wriggling in convulsions. After she has feigned suffering sufficiently long to have given him a lesson, she says: "Don't be afraid, Karol. Mummy will recover soon." Both scenes show her as an egoist willing to impose her will on the child and make him a blind follower of her orders. She tries hard to deprive him of free will and initiative, and she succeeds.

Both in the short story and the film, the Cupboard Man's stay in the home forms an important counterpoint to his mother's influence. Grzegorzek develops the role of Smith (as the film is set in Poland, Smith becomes Kowalski, its Polish equivalent, a common surname, and here too the Cupboard Man says that it does not sound much of a name); he teaches the boy to read, to listen to sounds, to move his body, and, what is most important, to be tough. "You have to learn to live alone. You must be tough. Don't let anybody hurt you." This advice is new item, absent in the short story. Thanks to it, the young man's reaction during the conflict in the restaurant kitchen is a logical consequence of Smith's teaching: for once in his life he manages to take the initiative and per-

\footnotetext{
5 See Bordwell and Thompson for more information on this type of framing (237).
} 
form an action instead of just following others' orders. But his energy is quickly spent and he returns to his cupboard. Although Smith's influence has helped him to become active for a while, it is his mother's influence that wins in the end and he retreats into his passivity. This is more deeply felt in the film as it omits the boy's shoplifting and then his imprisonment. His final inactivity (as in the book, he has not left his flat for three months at the time of narration) is clearly contrasted with his single sign of activity.

A powerful distinction between the film and the book is the escape sought by the main character. In both versions he longs to stay in the cupboard. In the short story he seeks the cramped peace of the womblike environment; the oven evokes in him both repulsion and attraction. In the chronology of the story presented in the book, the cupboard appears relatively late, as an attempt to return to the good days of infancy. In the film Karol finds escape in the cupboard as soon as his mother starts dating. And what he seems to be attracted by in the movie is not so much the limited space but the peace and quiet, and also the atmosphere of childhood. In his dreams he returns to the world of fairy-tales that his mother used to read him. Several of his dream scenes do much more than just signal his love of fairy-tales; in their complicated vision, in their oneiric quality and sophisticated symbolism they deserve an analysis going beyond the scope of this paper.

The film traces Oedipal strands in the mother's behaviour. She and Karol sleep in a big marital bed. Early in the film she carries her baby while looking at photographs of her late husband, and we hear extradiegetic music, a fragment of a song that must have been her and the husband's favourite. When, later, the same song is played on the radio, she takes Karol in her arms and dances with him.

An important stimulus for her change is a love scene on television that they watch together: a couple are kissing passionately. Shortly afterward, she searches through a drawer and finds a long-neglected bundle. Out of it she takes an object that she keeps in her closed fist. A close-up shows her unclenching the fist; she looks at the object with tension. It is a lipstick, blood red. In extreme close-up we watch her apply it to her lips. She dresses up and before going out kisses Karol on the forehead, leaving there a grotesque imprint of her blood-red lips (and this might be part compensation for the missing scene where the boy paints her red mouth with black inside, at the home; part compensation because here there is no black).

The Cupboard Man's voice-over ending the film, his confession that he wants to stay in his cupboard, leaves the viewer in no doubt that all his 
actions, the only exception his revenge on Pus-face, have been shaped by his mother. ${ }^{6}$ Grzegorzek's decision to omit all verbal signals of the son's hatred seems to have worked perfectly. The tragic consequences of the mother's domination are thus even more striking.

\section{WORKS CITED}

Bordwell, David, and Kristin Thompson. Film Art: An Introduction. Fifth edition. New York: McGraw-Hill, 1997.

Byrnes, Christina. The Work of Ian McEwan: A Psychodynamic Approach. Nottingham: Paupers' Press, 2004.

Childs, Peter, ed. The Fiction of Ian McEwan: A Reader's Guide to Essential Criticism. Basingstoke: Palgrave Macmillan, 2006.

Grzegorzek, Mariusz. “Żal tak młodo umierac.” Kino Nov. 1994: 12-13.

Kezich, Tullio. "Addio, madre crudele: meglio star chiuso dentro

l'armadio." Corriere della Sera 1 Sept. 1993: 21.

kjz. "Rozmowa z człowiekiem z szafy.” Gazeta Wyborcza 24 Feb. 1996, "Gazeta Telewizyjna": 4.

McEwan, Ian. "Conversation with a Cupboard Man." First Love, Last Rites. London: Pan, 1976.

---. Interview with Jerzy Jarniewicz. "Potrzebujemy nieprawdziwych mitów." Gazeta Wyborcza 30 Oct.-1 Nov. 1999: 20, 22.

Malcolm, David. Understanding Ian McEwan. Columbia: University of South Carolina Press, 2002.

Ryan, Kiernan. Ian McEwan. Plymouth: Northcote, 1994.

Slay, Jack Jr. Ian McEwan. New York: Twayne, 1996.

6 Although it might seem obvious that the story of the film should be interpreted literally, an Italian critic, Tullio Kezich, writing in the Italian press at the time of the Venice film festival in 1993, suggested a political reading. In his interpretation, Karol is Poland seen in her tortured and impossible relations with Mother Russia, and in her contemporary troubles in behaving as an adult nation. 